\title{
Millennials: New Environments and the Human Right to Work ${ }^{1}$
}

\author{
Gabriela Guadalupe Valles Santillán \\ Juarez University of the State of Durango \\ Karen Flores Maciel \\ Juarez University of the State of Durango
}

\begin{abstract}
This study will be limited to the examination of the human right to work as corresponding to the generation of the so-called Millennials. We will present a new working mode that is being conducted today through the use of new technologies: the so-called telework. Then, we will define who we refer to with the term Millennials, and a sketch of the social context in which the members of that generation live will be made, explaining how this new pragmatic environment has a significant impact on the working environment in which they carry out their activities, prompting the emergence of new requirements with respect to the improvement of the working conditions in which they develop their economic activities day by day. Finally, an analysis will be made of two modern institutions that, in the current work environment, have been built on the basis of Millennials' practices: the freelance and the startups.
\end{abstract}

Keywords: millennials, human right to work, internet, telework, freelance, startups

\section{THE INFORMATION, TECHNOLOGY AND INTERNET SOCIETY}

We are living in a time of remarkable changes on a global level, where the use of information and communication technologies (ICTs) plays a transcendental role. These changes are taking place on an unprecedented scale and at an unprecedented speed, with information being a fundamental element in transforming the life of human beings; from industrial and service societies, we are moving towards an information society.

The emergence of new technologies has given way to a different social and cultural reality, with industrialized countries no longer being the mainstay of the economy, but rather the positioning of technology itself, where the information society is present, converging with ICTs, since through them, knowledge is disseminated and exchanged within the community.

The information society is also a learning and knowledge society, for as technology progresses, it penetrates the lives of people and their environment. Thus, we can say that we are facing a technological revolution, which liberates the intellect, given that today the handling of information by automated means marks the information societies, where the massive use of ICTs to disseminate and exchange knowledge is taking place ${ }^{2}$, developing agents that transform the State.

Information allows borders to disappear, as the flow of cross-border data allows territorial boundaries to be demolished, with this information being acquired almost immediately. 
Knowledge is information that has been interpreted and personalized, that has added value, that is also oriented towards decision making and that serves as potential information for other people ${ }^{3}$.

Access to information is a fundamental human right, and ICTs have the potential to promote the emergence of a global information society. The developing countries must be able to move towards a technological world, with all that would entail, leaving behind social delays that generate technological and, consequently, social gaps; in other words, they must work to reduce, to the extent of their possibilities, the digital gap, understood as the inequality between those who have access to information and communication technologies and those who do not -mainly to the use of the Internet.

The Internet is a means of communication that allows, for the first time, communication between multiple groups of people in a chosen time and on a global scale. Just as the spread of the printing press in the West gave rise to -what McLuhan called- the Gutenberg Galaxy; in other words, we have now entered a new world of communication: The Internet Galaxy ${ }^{4}$.

The internet being an information and communication technology, and not one that is a mere discovery, it becomes a new instrument for the transformation and development of a country in the economic and social field, as well as in the institutional environment of democracy, among others.

The Internet is now the technological basis of the organizational form that characterizes the information age ${ }^{5}$. The use of the Internet as a communication system and as an organizational form of society, made its appearance in the last years of the 20th century. At the end of 1995, the first year of widespread use of the world wide web, there were some 16 million users of computer communication networks worldwide. At the beginning of 2001, there were over 400 million; in 2005 there were about 1 billion; by 2010 the figure was roughly 2 billion; and finally, by 2015, the number of Internet users stood at over 3.1 billion $^{6}$. All these figures are relevant considering the lack of Internet diffusion in less developed countries and, consequently, with a technological gap.

That said, the influence of the Internet goes beyond the number of users, since what matters is the quality of the uses of the network. Currently, the main economic, social, political and cultural activities worldwide are being structured through the Internet ${ }^{7}$; in fact, being left out of these networks is the most serious form of exclusion that can be suffered.

There is no doubt that today's generations, such as the Millennials, for example, learn the new communication codes swiftly, since this reality is not new to them, having been born or raised in it; they are referred to as digital natives. The Internet offers the possibility to any person to be, at the same time, receiver and transmitter in the communication process, that is to say, that every person, through the use of information and communication technologies, becomes a means of communication by themselves; opening the doors to new models of information transmission.

The impact of technology has made the Internet the ideal place to carry out a variety of activities of widely different natures -the traditional has turned into the technological-, as is the case of the work system, where we can observe elements that have adapted to the virtual environment.

\section{TELEWORK, A NEW WAY OF WORKING THROUGH THE USE OF TECHNOLOGY}

The information and internet society brought with it a profound reformulation of the way of working, modifying habits that had been constant for centuries, opening up new possibilities that were previously unsuspected, such as working from anywhere, through the use of technological tools.

Initially, in industrial processes related to work in large factories, the employers or owners exercised direct control over their workers; therefore, the employment relationship was carried out in industrial plant facilities ${ }^{8}$.

Later, a stage of coexistence with traditional forms of work development arose, for example: homeworking as an exception to the work system then in force, whose purpose was to serve as a complement to the work carried out in large factories ${ }^{9}$.

Afterwards, during the emergence and establishment of personal computers, a process of development of the information society began, and a new way of producing goods and services in parallel 
to those produced in large industrial complexes was revealed, a situation that became known as teleworking ${ }^{10}$.

The physicist Jack Nilles, who introduced the term telecommuting in the United States, worked for communication systems of the National Aeronautics and Space Administration, better known as NASA, and is also known as the father of telework.

Jack Nilles, thought about the possibility of taking the job to the worker instead of the worker to the $j o b$, referring to the option of performing work tasks outside the usual place. It was the time of the oil crisis at the beginning of the 1960s, a time when energy saving was a priority, as well as avoiding the need to travel as much as possible, using the small computer tools that existed at the time ${ }^{11}$.

Today, the word telework makes us see and think about work in a different way, better adapted to the information society, which so requires.

Hence, the concept of teleworking necessarily involves two basic fundamental elements, which are: distance, and the use of telecommunications ${ }^{12}$. One of the definitions given for this precept, is the one indicated by Fernando Monsalve Balaúl ${ }^{13}$, which is detailed as follows:

A definition given by the International Labour Organization (ILO) for "remote work" (today clearly understood as telework) is quite complete and clear, and states that it is "a form of work in which work is carried out in a place away from headquarters or production facilities, thus distancing the worker from personal contact with other workers"; new technologies allow this distancing with the help of communication.

In this respect, it is important to establish the difference between teleworkers and tele-employees, the latter generally referring to persons who have an employment relationship with a given company; that is, they are employees of the company, and therefore may be subject to working hours, even if they work outside the company, in a distant location or at home. Teleworkers are those who do not have an employment relationship; consequently, their activity is a service provision, not an employment relationship, and not exclusive to a single company, meaning they can provide services to various clients, and therefore are self-employed ${ }^{14}$.

In this sense, we are faced with the increase and development of activities that do not require physical presence to be carried out, such as the areas of computer science, education, communication, finance, and consulting in different areas, among others, with an increasing number of people becoming involved on a daily basis in carrying out their tasks through telematic means, motivated by the innumerable advantages they bring with them. Teleworking is a modality that is oriented towards obtaining more and better results.

It implies the spatial delocalization of the services provided, generating multicultural and diverse environments that enrich the tasks and their actors ${ }^{15}$. At present, many of the services are based on cloud computing, understood as a set of software and services hosted on a server connected to the network, accessible from any computer (whatever its operating system) with an Internet connection and without the need to install executable applications on its hard drive, and where the information generated by these same applications or services is also stored ${ }^{16}$; in this sense, companies do not need to have IT infrastructure in their own offices, which significantly reduces risks and costs.

Today then, the word teleworking leads us to consider the execution of work through technological tools, in a more flexible way, adapting to an information society that demands it.

In general, it is already difficult to conceive our activities without the use of technology, since we spend much of our time connected in one way or another, and in that respect, work is no exception. The need for presence disappears in the face of the various possibilities of work offered by technology and wireless connection, marking real savings and optimizing the time factor, which has become the scarcest to obtain nowadays.

On the other hand, face-to-face activity conspires against technological innovation, which pushes us to virtual environments, where online work, based on connectivity, constitutes an absolute comparative advantage, since it enables us to provide a real time and instantaneous response to the demands that may arise 24 hours a day, regardless of physical location. 
In that regard, it is considered relevant to make a brief summary of the advantages and disadvantages that some jurists have noted about teleworking. Thus, we have that Dr. Felipe Miguel Carrasco Fernánde ${ }^{17}$, considers as advantages of this new modality of work, the following ones:

a) More importance is given to the objective achieved rather than to the completion of a work schedule;

b) The teleworker/tele-employee has more time and autonomy, since they can better organize their commitments and social, family, leisure, recreation and study interests, among others;

c) The company will have workers specialized in the specific branch of teleworking;

d) Greater autonomy, creativity, competitive ability and performance, among others, is generated in teleworkers/tele-employees.

e) Savings in physical space, equipment, electricity and maintenance are achieved;

f) The most is made out of work because it can be done at the home of the teleworker/teleemployee or anywhere else;

g) Telework can be developed in the various sectors in which the company is involved;

h) Environmental pollution and vehicle traffic problems are reduced;

i) The integration of people with disabilities into the working environment is made possible;

j) Workplace absenteeism is reduced or avoided;

k) Government public policies can encourage programs for the development of telework in diverse communities, and

1) Time is optimized in favor of the company and the teleworker/employee, since the latter's physical presence is no longer required.

Although the advantages are varied, the truth is that we also find the existence of some disadvantages regarding telework; thus, authors such as José Francisco Espinoza Céspedes and Ana María Martínez Berndt $^{18}$, point them out as follows:

a) In order to satisfy the job requirements of his employer, the teleworker/tele-employee may incur in lengthy and tedious teleworking sessions that could hinder his personal and professional development;

b) In some cases, psychological problems can arise from isolation;

c) If the teleworker/tele-employee is not orderly or methodical, there may be a case where he fails to meet his contractual obligations on time, and

d) Job insecurity for the teleworker/tele-employee.

Having noted the above, it should be clarified that in spite of the negative points about the implementation of telework, the truth is that in general, there is a favorable scenario for the proper positioning of this new mode of work, since today's society naturally interacts with technology. The world has become globalized and this means that borders are no longer an impediment to the development and growth of the virtual environment without the need to travel, aligning itself on the path of collaborative and network guidelines.

For this reason, countries should be led to a more effective implementation of public policies on telework and the creation of specific commissions, as well as to solve the urgent need to legislate on this subject. Having legislation on the specific subject will allow the options for inclusion and growth to be increased, with an appropriate framework of reference so that companies have confidence when choosing it as an alternative in the production and diversification of tasks, and also to avoid abuses in the areas of remuneration, working hours, evaluation, and professional development, among others.

In view of all these reasons, it is essential to adapt the system of labor regulations so that the countries consider this modality as a new form of work, which must be understood, protected and promoted through specific programs aimed at its development and strengthening, and to spread its benefits in order to avoid prejudices and mistakes, rooted in old ways of thinking.

In this vein, and knowing that teleworking leads to the cross-border nature of tasks, it is necessary for countries to adopt similar regulations so that disputes do not arise to the detriment of those who carry out the work, which will require research and comparison of options to create model laws. 
In a world with high rates of unemployment, the option of teleworking offers a concrete possibility that will have to be supported by incentive-based policies that allow for adequate and permanent training for the definitive inclusion of a large mass of workers who would otherwise be gradually marginalized from the labor force.

Finally, it should be mentioned that the European Framework Agreement on Telework, signed on 16 July 2002 in Brussels, provides for the control of telework to be in the hands of the actors themselves, trade unions and employers in accordance with the legislation of each country, based on reciprocity through international treaties.

\section{THE CURRENT CONTEXT IN WHICH THE MILLENNIALS LIVE: IMPLICATIONS IN THE FIELD OF WORK THAT IMPACT ON THE HUMAN RIGHT TO WORK}

The so-called Millennial generation corresponds to those who were born between the years 1980 and 1995 approximately, that is, at the end of the 20 th century $^{19}$.

According to this fact, we can see that the Millennials are adults who currently range from 22 to 37 years of age and are therefore active -or at least potentially so- in a different context in which legal, political, economic, social and cultural factors play a role. By this, it is understood that the Millennials are individuals who, according to the classic conceptions of civil law, have legal capacity to enjoy rights, on the one hand, and legal capacity to exercise, not only rights -in a very personal way-, but also obligations $^{20}$.

Thus, for example, in Mexico, the Millennials are citizens in the exercise of their civil, labor and political-electoral rights, except, of course, those specific cases in which some legal situation is configured that prevents the exercise of such rights to the fullest. The same is certainly true in other parts of the world, where -at least legally speaking- the exercise of civil and political rights and obligations depends, to a great extent, on the factor of coming of age -with the consequent access to citizenship of the corresponding State- and other factors to be considered in order to be subject to topics of such nature, as well as with regard to the exercise of rights and obligations of a labor nature

In this regard, the Convention on the Rights of the Child $^{21}$ states that the establishment of a minimum legal age is a mandatory requirement for the member states of this international instrument, noting a consensus to standardize minimum age for the exercise of various rights and obligations -among these, the minimum age for admission to employment- taking as a reference point the range of eighteen years of age, and on this, establishing higher or lower ages, depending on the right or obligation to exercise.

For Mexicans, this age limit -eighteen years old- is considered a requirement to be a citizen of the Republic, in accordance with Article 34 of the Mexican Constitution.

Based on the above data, the Millennials are young adults- between 22 and 37 years of age- who therefore actively participate in the daily context giving meaning to new perspectives of legal, political and social organization in contemporary democratic states.

Along these lines, it is easy to deduce that the Millennials currently accompany other generations of social cohorts in the exercise of means of citizen participation such as referendums, plebiscites, electoral processes, popular initiatives and consultations, the revocation of mandates and, in general, any other mechanism through which it is intended to give substance to the public interest and increase the quality of the population's living conditions.

The Millennials are currently revolutionizing the world with their ideas and their rather peculiar way of seeing and living life.

This generation, precisely for being born at the end of a century in which innumerable technological advances were developed -especially during the second half of the 20th century- has witnessed a paradigm shift in the communication networks between people, pressure and power groups, as well as between entire nations, overcoming the barriers of distance and temporality in the processes of information exchange. This paradigmatic change is the defining point of a new context in which the present generations are living today, especially the Millennials, since they are the ones who, to a great extent, have motivated it. 
This new context includes the following aspects, just to list a few ${ }^{22}$ :

- New modalities and conditions of work: an example of this are those that usually occur in freelance work -independent teleworking- or those offered by so-called startups or emerging companies and some other transnational technology companies such as Google and Facebook, just to make some reference. The above, consequently, brings with it the emergence of new forms of revenue collection, which even tend to escape the State's control and regulation of contributions to public finances, as part of the obligations of citizens.

- The regulation of innovative payment networks: such as the new currencies circulating in cyberspace, called cryptocurrencies, which are based on a format or record of decentralized and algorithmic encryption by blockchain ${ }^{23}$.

- Novel forms of service contracting: for example, the so-called smart contracts, which are far from the traditional models still contemplated by current civil, labor and commercial legislation.

The innovative and multifaceted character that the Millennials develop transcends in a very particular way in the context of today's work relations; this, to the point -even- of generating discomfort among the other generations that precede them in age, because of how irreverent the Millennials can become in the eyes of their employers or bosses, hierarchical superiors, co-workers and even their own subordinates... all this, in a work environment. ${ }^{24}$

Meghan M. Biro, writer at the famous business magazine Entrepreneur, refers to the following: ${ }^{25}$

Millennials have taken the workplace by storm. They're now the largest generation in the workforce and are tossing the 9-to-5 day, with dedicated cubicles and shared offices, out the window. They have fresh ideas for how, when and where we work, and as the younger Generation $\mathrm{Z}$ starts clocking in, organizations that haven't prioritized flexibility and mobility risk losing out on top tier talent.

...

Millennials are mostly comfortable with change. If they take a job at one company, and start to feel overworked or undervalued, they'll just move on to another company...

Millennials are not lazy. In fact, it's quite the opposite. If they have an employer that enables them to do so, they'll skillfully blend their work and personal lives to get the balance they're looking for.

Just because millennials will job hop rather than stay where they're unhappy doesn't mean they're disloyal...

Millennials want opportunities to grow and explore their skill sets

The author of reference, in turn, refers to surveys and studies published relatively recently on the Millennials in the context of employment. ${ }^{26}$ Thus, to quote one of these studies, Bentley University, in the results of an analysis published in 2014, presented the following data about the needs and preferences of Millennials in their workplaces: ${ }^{27}$

- They demand that the sources of work contemplate flexibility in working hours.

- Similarly, that there is the possibility of doing the work at a distance; in fact, that there is the possibility of working from your own home or any other place.

- That the periods dedicated to rest during the working day be increased, and that among the employment benefits, institutional benefits aimed at the health care and recreation of workers be contemplated.

- Bentley University respondents alluded to the need for greater immediacy with their bosses, employers, or superiors. 
- They point out the need to enjoy good salaries and working environments that motivate social coexistence.

From the above, it can clearly be seen that, in those parts of the world where technology plays a transcendental role in the development of work activities -and where the Millennials, for that very reason, have begun to revolutionize the context with their innovative ideas-, there is an urgent need for a revision -or even a reinvention- of the applicable legal framework, starting by building the constitutional foundations that prove to be conducive, in order to achieve a real optimization of the rights of freedom of people who are involved with this type of generational paradigm shift, highlighting -of course- what corresponds to the human right to work, given that this is the subject of this research.

\section{FREELANCE AND STARTUPS: OPTIMIZATION OF THE HUMAN RIGHT TO WORK}

In this section we will make a brief allusion to the new institutional neologisms that the Millennials have given rise to in the occupational context: freelance and startups.

It is considered important to bring up these concepts, given that the role they play in everyday life allows us to identify and take into consideration a series of pragmatic elements that can be useful when seeking -from the academic scope that corresponds to us- strategies and actions to optimize the human right to work, with a perspective of benefit and better living conditions for the new generations that have joined economic activities, and therefore, the world of work.

The methodology that will be used in this part of the research will be through the formulation -and consequent answer- of two questions, which will be reproduced in each concept to be analyzed -freelance and start-ups-, respectively: what are they, and in which economic fields or activities -within the labor context- can we find them? Subsequently, a joint answer will be given to the question: what pragmatic aspects can we rescue from these concepts, in order to achieve an optimization of the human right to work?

Let's start with the argumentative development in the specified terms:

\section{Freelance}

First of all, what is freelancing? The terminology points -in the current real context- to the realization of work in an independent way, which, in fact, has already been alluded to with teleworking. The "Selfemployed or freelancer: They offer their services themselves from their own home"28, refers the researcher Julio Tellez; however, we could say that the freelancer subject does not necessarily occupy his own home to work autonomously and offer his services, but he can do it practically from anywhere, as long as he has the indispensable inputs and tools to carry out his job, which -among Millennialstranslates more than anything into the necessary availability of modern technologies -primarily access to the Internet-.

A freelancer is a service provider from a remastered contracting perspective; in the strict sense, they do not have a boss or hierarchical superior -although what they can have are collaborators or cofreelancers-, and they are hired by those who require their services, under an innovative scheme of delivery of results adaptable to the times and ways of the freelancer themselves. ${ }^{29}$

Freelancing is quite related to the concept of entrepreneurship. Being an entrepreneur has to do with starting a business, and this is done on your own -individually or collectively-, in the sense that the economic activity to be started is based on an original idea that can fit into the market. To this end, "The business literature gives us approximations to the meaning of entrepreneurship, which is synonymous with innovation, paradigm change or risk taking". ${ }^{30}$

A large-scale business entrepreneur can emerge from the practice of freelancing, if the aim is to broaden the focus and coverage of the service offered at an early stage. Such an intention may give rise to a startup -an emerging company- or give direction to a more experienced business project.

Secondly, in what fields or economic activities -within the work context- can we find the freelancer? According to data released in 2014, derived from the application of field techniques, by the network of universities Universia, aimed at freelancers in nine Latin American countries, in Mexico $37 \%$ of 
respondents said that being freelancers is beneficial because, through this employment alternative, it is possible to carry out several projects at once, and learn from each of them. ${ }^{31}$

Based on this, and for the particular case of Mexico, it is easy to find freelancers in the field of publishing and graphic design, as well as in the area of web development; likewise, there are those who mention that virtual platforms that support economic activities -worldwide- such as uber and airbnb, host freelancers for their own development; However, others oppose such assertion, arguing that the people who perform the activities that host these platforms are not freelancers, but simply employees that support them. ${ }^{32}$

\section{Startups}

They are emerging companies, or in the experimental or pilot stage. On that note: ${ }^{33}$

'A startup is a large company in its early stage; unlike an SMB, a startup is based on a business that will be scalable more quickly and easily, by making use of digital technologies'...

Leading technology giants such as Facebook, Google, Airbnb and Uber started out as startups; however, at this point they can no longer be considered in that category.

Mexico, for example, has paid special attention to these projects since, in 2011, the first incubators and direct support to technological startups were created.

In 2016, the study "Startup Latin America 2016: Building an Innovative Future", conducted by the OECD, determined that Mexico is the country that most supports these initiatives within the nations that make up the Pacific Alliance.

Startups are definitely part of the private business sector, and although they are incipient projects -so to speak- but with great ambitions, the truth is that they fit into the category that should be regulated by labor standards -regardless of the fiscal, financial and administrative regulation that also corresponds to them-.

However, it should be noted that startups contemplate a panorama of working conditions somewhat divergent from the conventional legal parameters, although, on the other hand, very much ad hoc to what the Millennials demand.

The startups make use of a novel leadership that is characterized by mentality change -a neuroinnovative leadership- ${ }^{34}$ the leaders "...have the ability to see the world differently and therefore are considered free thinkers, visionaries, avant-garde, outthinkers, geniuses, innovators, creatives, rebels, heretics... pioneers, infidels, madmen... subversives, stirrers... reformers, insurgents... reckless... among other names". ${ }^{35}$

The working environment offered by startups and those companies that, from being emergent, will later consolidate into titans of the innovation market, is well suited to the employment demands of Millennials.

The working conditions provided by these institutions offer a collaborative environment in which an inclusive and flexible philosophy is promoted, making the workday smoother -which is not exactly in line with the traditional concept of working day as contemplated in current labor legislation-, making it more enjoyable and encouraging worker creativity. This, even though in certain cases the working hours may even exceed the maximum number -or even the number of overtime hours- contemplated by labor laws: startups “... operate with a 'work hard, play hard' mentality. While you'll enjoy plenty of happy hours and ping pong tournaments, you'll also find the work intensely demanding...",36

These working conditions, by motivating creativity and being inclusive, are considered to optimize the principle of the dignity of the person; and in that sense, although these companies do not cease to 
pursue a capitalist objective, it cannot be denied that, from a broad point of view, they are precursors of respect for human rights.

Among the working conditions accepted by startups are flexible working hours, as well as the development of distance working activities; there is no strict dress or appearance code; any religion is acceptable; there is no distinction to the detriment of the worker based on sex, sexual orientation, race, or being single, married or living in a union. ${ }^{37}$ All this, just to mention some circumstances that in a traditional work context, have come to harm the rights of workers or have made unreasonable distinctions between people.

Finally, in which economic fields or activities -within the labor context- can we find startups? Currently we can place this business category in all types of economic activities, highlighting those that take place in the field of technological innovation, such as the famous Silicon Valley -located in northern California, United States-.

It is already very common to find these enterprises in Mexico, likewise, in the technological innovation field and also in education, where Mexican Millennials -like the founders of the Veracruz startup Product Tracker, which turns common objects into intelligent products, or the creators of Impulsarte, originated in Jalisco, a startup that houses an officially valid online music academy--, ${ }^{38}$ are giving a new twist to the range of available possibilities to exercise the human right to work, and in general to exploit the skills of critical and creative thinking not only to achieve personal goals, but also to satisfy the general interest of society.

Finally, we have the following question: what pragmatic aspects can we rescue from freelance and startups, in order to achieve the optimization of the human right to work?

From a neo-constitutionalist and principled fundamental rights perspective -such as that of Robert Alexy- legal norms that recognize these types of rights are mandates for optimization, and therefore, "...they must be applied to the greatest extent possible in accordance with the legal and factual circumstances of the case...". 39

Taking into account this iusphilosophical conception, and relating it to the topic addressed in this section of the research, the pragmatic aspects that can be rescued both from the freelance practice and startups -as institutions that are part of current reality, and that can be useful to achieve the referred optimization in the field of the human right to work-, would be those novel contextual conditions, And while they may be somewhat outside the current conventional legal framework, the truth is that they motivate, encourage and increase people's capacities and skills, as well as their attitude towards work, in a positive sense, given that they promote a flexible collaborative environment, with immediacy between leaders and subordinates, but also with hard work to achieve satisfactory results.

Consequently, it is considered that the conglomerate of legal norms that recognize and protect the human right to work should review and contemplate these innovative schemes in order to lead to an efficient regulation of them, so as to be in line with the factual circumstances that prevail today in the lives of contemporary generations, such as those of the Millennials and their successors.

\section{CONCLUSIONS}

First- The information society is also a learning and knowledge society, for we are facing a technological revolution, a liberation of the intellect, where information and communication technologies (ICTs) are used predominantly with the intention of spreading knowledge and exchange in a society. Information is making borders disappear.

Second- The Internet is a communication medium that allows the exchange of ideas between groups in real time and on a global scale. The Internet becomes a new instrument for the transformation and development of a country, in the economic, political and social fields. The Internet is the technological pillar of the new organizational form that characterizes the information age.

Third- The Internet emerges as a space where different types of activities are carried out, such is the case of the work system, which visibly begins to adapt to the virtual environment, in what has been called, from a generic perspective, telework; that is, working from any place, through the use of 
technological tools, for today face the increase and development of activities that do not require material presence to be carried out.

Fourth- The Millennials have not only come to revolutionize the social context in which labor relations unfold today, but have also questioned the efficiency and pragmatic effectiveness of the national and international legal framework that seeks to fulfill the purpose of optimizing the human right to work, introducing new requirements and demands with respect to the conditions in which economic or production activities are carried out, which implicitly brings about a change in labor relations arising from supra to subordination.

Fifth- A latent example of the new practices of the Millennials, in which it is clearly possible to notice a new course in the evolution of working conditions -individual or collaborative, subordinate or non-subordinate-, is constituted by both the freelance -which comes to be a color of the telework gamutand the startups; this, emphasizing that, from both institutional figures, it is possible to rescue pragmatic aspects -substantial and attitudinal- that can be useful to achieve the referred optimization in the scope of the human right to work, being considered viable, for the achievement of that end, a reinvention of the corresponding legal framework

\section{ENDNOTES}

1. This study was originally presented by the authors in Spanish, as a chapter (pp. 81-108) of the open access book "Trabajo y Derechos Humanos: algunos retos contemporáneos" (Labor and Human Rights: contemporary challeng-es), coordinated by Arroyo Cisneros, Alán and Montoya Zamora, Raúl, which was edited and published by Juarez University of the State of Durango in 2017, http://investigacionesjuridicas.ujed.mx/includes/docs/trabajoyderechos.pdf

2. Téllez Valdés, Julio, Derecho Informático, 4th ed., Mexico, Mc Graw-Hill, 2008, p.1.

3. Inclusive Information Society: Analysis of the Latin American and Caribbean Region, http://iibi.unam.mx/publicaciones/255/acceso_abierto_informacion\%20sociedad\%20de $\% 201 \mathrm{a} \% 20 \mathrm{informac}$ ion\%20incluyente\%20Egbert\%20Sanchez\%20Vanderkast.html

4. Castells, Manuel, La galaxia Internet. Reflexiones sobre Internet, empresas y sociedad, Barcelona, Editorial de Bolsillo, 2003, p.16.

5. Ibid., p.15.

6. Id.

7. Id.

8. Espinoza, José Francisco and Martínez Berndt, Ana María, "Generalidades en relación con el teletrabajo (Generalities regarding telework)", Teletrabajo en Iberoamérica, Mexico, Popocatépetl Editores, S.A de C.V., 2013, p. 119.

9. March, Cristina, Implantación del Teletrabajo en la Empresa. Barcelona, Gestión 2000, 2000 p. 11.

10. Espinoza, José Francisco and Martínez, Ana María, Op. cit., p.119.

11. Clara, Bibiana, "La evolución del teletrabajo en Argentina (The evolution of teleworking in Argentina)", Teletrabajo en Iberoamérica, Mexico, Popocatépetl Editores, S.A de C.V., 2013, p.104.

12. Carrasco Fernández, Felipe Miguel, "Trabajo informal: teletrabajo en México (Informal work: teleworking in Mexico)", Asociación Iberoamericana de Juristas del Derecho del Trabajo y la Seguridad Social, http://aijdtssgc.org/2009/11/20/trabajo-informal-teletrabajo-en-mexico/

13. Monsalve Basaúl, Fernando, "Los teletrabajadores (The teleworkers)", Revista de Derecho de la Universidad Católica de la Santí-sima Concepción, Santiago de Chile, number 11, year 2003, p. 224.

14. Carrasco Fernández, Felipe Miguel, op. cit

15. Clara, Bibiana, op. cit., p.104.

16. Lamata, Eloísa, "Cloud Computing': qué es, para qué sirve y cuáles son sus aplicaciones ('Cloud Computing': what is it, what is it for and what are its applications)", El economista, http://www.eleconomista.es/gestion-empresarial/noticias/4087167/07/12/Cloud-Computing-que-es-paraque-sirve-y-cuales-son-sus-aplicaciones-.html

17. Carrasco Fernández, Felipe Miguel, "Teletrabajo (Telework)", Teletrabajo en Iberoamérica, Mexico, Popocatépetl Editores, S.A de C.V., 2013, p.12.

18. Espinoza, José Francisco y Martínez, Ana María, Op. cit., p. 122 
19. This is what Krauze, Enrique, refers to in "El misterio de los millenials (The Mystery of the Millennials)", June 5, 2016, http://www.enriquekrauze.com.mx/joomla/index.php/opinion/97-art-critica-social/976- elmisterio-de-los-millennials.html

20. "The freedom recognized by law for its recipients to participate personally in life in active legal life (...) is the essence of the capacity to exercise (...)", in Domínguez Martínez, Jorge A., "Capacidad e incapacidad de ejercicio (Exercise capacity and inability)", Revista Mexicana de Derecho. Colección Colegio de Notarios del Distrito Federal, Mexico, no. 16, 2014, p.45, https://revistas-colaboracion.juridicas.unam.mx/index.php/rev-mexicanaderecho/article/viewFile/14134/12623. The above, in con-trast to the simple capacity to enjoy rights and prerogatives, among which human rights themselves should be highlighted.

21. See the document published by the United Nations Children's Fund, Minimum Legal Ages and the Realization of the Rights of Adolescents. A review of the situation in Latin America and the Caribbean, UNICEF, January 2016, https://www.unicef. org/lac/20160406_UNICEF_Edades_Minima_Esp(1).pdf

22. A similar argument was made by the author Valles Santillan, Gabriela Guadalupe, in "Los millennials y la Constitución Política de los Estados Unidos Mexicanos de 1917: Perspectivas y retos a 100 años de su promulgación (The Millennials and the Political Constitution of the United Mexican States of 1917: Perspectives and challenges 100 years after its promulga-tion)", La Constitución de 1917. Cien años después, Mexico, UJED and others, 2017, p.356.

23. See Fernández Burgueño, Pablo, "¿Qué es bitcoin, Blockchain, Token... (What is bitcoin, Blockchain, Token...)", 3 Sep-tember 2017, https://www.ivoox.com/que-es-bitcoin-blockchain-token-audios-mp3_ rf_20663609_1.html

24. See Carrillo Hernández, Juan Pablo, "Idiotas empoderados: La nueva clase que está de cidiendo el futuro de la humanidad (Empowered idiots: The new class that is deciding the future of humanity)", 11 September 2016 , http://pijamasurf.com/2016/11/ idiotas_empoderados_la_nueva_clase_que_esta_decidiendo_el_futuro_de_la_humanidad/

25. Biro, Meghan M. "Did Millennials Kill the 9-to-5 Workday, or Just Point Out That It's Dead?", 23 March 2016, Entre-preneur Media, Inc., https://www.entrepreneur.com/slideshow/306560

26. See the global generational study conducted by PwC, the University of Southern California and the London Business School, "Millennials value greater flexibility, appreciation, team collaboration and global opportunities", 2013, https://www.pwc.com/gx/en/hr-management-services/pdf/pwc-nextgen-study2013.pdf

27. Bentley University, "Millennials at work", PreparedU: The Millennial Mind Goes to Work, 11 November 2014, http://www.bentley.edu/newsroom/latest-headlines/mind-of-millennial

28. Téllez Valdez, Julio Alejandro, "Teletrabajo (Telework)", Panorama Internacional de Derecho Social, 1st ed., Mexico, Instituto de Investigaciones Jurídicas de la UNAM, 2007. p. 734,

https://archivos.juridicas.unam.mx/www/bjv/libros/5/2458/43.pdf

29. Gómez, Edith, "7 hábitos de los freelancers que debes dejar de hacer (7 freelancer habits you should stop)", 2017, Entre-preneur Media, Inc., https://www.entrepreneur.com/article/304331

30. Martínez Rivera, Sergio E. and Rodríguez Díaz, Luis Fernando, "Emprendedurismo social en México: hacia un modelo de innovación para la inserción social y laboral en el ámbito rural", Revista Estudios Agrarios, Mexico, No. 53-54, January-December 2013, p. 104, https://www.pa.gob.mx/publica/rev_53-54/analisis/emprendedurismo.pdf

31. Olivares Alonso, Emir, "Jóvenes mexicanos prefieren tener empresa propia o ser freelance (Young Mexicans prefer to have their own business or be freelancers)", La Jornada en línea, Mexico, 23 December 2014, http://www.jornada. unam.mx/2014/12/23/sociedad/035n1 soc

32. Reuters Staff, "Uber driver is employee, not freelancer: Swiss agency", Reuters, Zurich, 5 January 2017, https://www.reuters.com/article/us-swiss-uber/uber-driver-is-em-ployee-not-freelancer-swiss-agencyidUSKBN14P0J9

33. Dorantes, Ricardo, in "Qué es una startup", 9 November 2017, Entrepreneur Media, Inc., https://www.entrepreneur.com/article/304376

34. Muñoz Gutiérrez, Ramón, Innovación a la mexicana. Más allá de romper paradigmas (Mexican-style innovation. Beyond breaking paradigms), 1st ed., Mexico, Penguin Random House Grupo Editorial, 2014, p. 65.

35. Ibid. p. 66 .

36. Augustine, Amanda, "7 Ways to Survive and Thrive at a Startup", 8 October 2013, Entrepreneur Media, Inc., https://www.entrepreneur.com/article/228737 
37. In this regard, reference is made to Atipica, which is a startup initiated by Mexican -Laura I. Gomez- based in the United States of America, whose activity consists of offering other companies inclusive recruitment of human resources, through the use of new technologies, with the peculiar characteristic that the profiles recruited obey objective parameters -skills, talent and compatibility of individuals with the company-, overlooking race, religion, sexual orientation and socioeconomic level. See TagCDMX note, " Atipica, una startup mexicana contra la discriminación laboral (Atipica, a Mexican startup against labor discrimination)", 2017, Televisa S.A. de C.V, http://tagfestival.com/2017/05/09/atipica-startup-mexicana-contra-discriminacion-laboral/

38. See November 2017 digital edition of Entrepreneur, Entrepreneur Media, Inc., https://www.entrepreneur.com

39. Alexy, Robert, and García Figueroa, Alfonso, Star Trek y los derechos humanos (Star Trek and Human Rights), 1st ed., Valencia, Tirant Lo Blanch, 2007, p. 82.

\section{REFERENCES}

Alexy, R., \& García Figueroa, A. (2007). Star Trek y los derechos humanos (1st ed.). Valencia, Tirant Lo Blanch.

Augustine, A. (2013, October 8). 7 Ways to Survive and Thrive at a Startup. Entrepreneur Media, Inc. Retrieved from https://www.entrepreneur.com/article/228737

Bentley University. (2014, November 11). "Millennials at work", Prepared: The Millennial Mind Goes to Work. Retrieved from http://www.bentley.edu/newsroom/latest-headlines/mind-of-millennial

Biro, M.M. (2016, March 23). Did Millennials Kill the 9-to-5 Workday, or Just Point Out That It's Dead? Entrepreneur Media, Inc. Retrieved from https://www.entrepreneur.com/slideshow/306560

Carrasco Fernández, F.M. (2013). "Teletrabajo", Teletrabajo en Iberoamérica. Mexico, Popocatépetl Editores, S.A de C.V.

Carrasco Fernández, F.M. (n.d.). Trabajo informal: teletrabajo en México. Asociación Iberoamericana de Juristas del Derecho del Trabajo y la Seguridad Social. Retrieved from http://aijdtssgc.org/2009/11/20/trabajo-informal-teletrabajo-en-mexico/

Carrillo Hernández, J.P. (2016, September 11). Idiotas empoderados: La nueva clase que está decidiendo el futuro de la humanidad. Retrieved from

http://pijamasurf.com/2016/11/idiotas_empoderados_la_nueva_clase_que_esta_decidiendo_el_fu turo de la humanidad/

Castells, M. (2003). La galaxia Internet. Reflexiones sobre Internet, empresas y sociedad. Barcelona, Editorial de Bolsillo.

Clara, L.B. (2013). La evolución del teletrabajo en Argentina. Teletrabajo en Iberoamérica. Mexico, Popocatépetl Editores, S.A de C.V.

Domínguez Martínez, J.A. (2014). Capacidad e incapacidad de ejercicio. Revista Mexicana de Derecho. Colección Colegio de Notarios del Distrito Federal, Mexico, no. 16. Retrieved from https://revistas-colaboracion.juridicas.unam. $\mathrm{mx} /$ index.php/rev-mexicanaderecho/article/viewFile/14134/12623

Dorantes, R. (2017 November 9). Qué es una startup. Entrepreneur Media, Inc. Retrieved from https://www.entrepreneur.com/arti- cle/304376

Entrepreneur Media, Inc. (n.d.). Retrieved from https://www.entrepreneur.com

Espinoza, J.F., \& Martínez Berndt, A.M. (2013). Generalidades en relación con el Teletrabajo. Teletrabajo en Iberoamérica, Mexico, Popocatépetl Editores, S.A de C.V.

Fernández Burgueño, P. (2017, September 3). ¿Qué es bitcoin, Blockchain, Token...? Retrieved from https://www.ivoox.com/que-es-bitcoin-blockchain-token-audios-mp3_rf_20663609_1.html

Gómez, E. (2017). 7 hábitos de los freelancers que debes dejar de hacer. Entrepreneur Media, Inc. Retrieved from https://www.entrepreneur.com/ar- ticle/304331

Krauze, E. (2016, June 5). El misterio de los millenials. Retrieved from http://www.enriquekrauze.com.mx/joomla/index.php/opinion/97-art-critica-social/976-elmisterio-de-los-millennials.html 
Lamata, E. (n.d.). "Cloud Computing”: qué es, para qué sirve y cuáles son sus aplicaciones. El economista. Retrieved from http://www.eleconomista.es/gestionempresarial/noticias/4087167/07/12/Cloud-Computing-que-es-para-que-sirve-y-cuales-son-susaplicaciones-.htmlM

March, C. (2000). Implantación del Teletrabajo en la Empresa. Barcelona, Gestión.

Martínez Rivera, S.E., \& Rodríguez Díaz, L.F. (2013, January-December). Em- prendedurismo social en México: hacia un modelo de inno- vación para la inserción social y laboral en el ámbito rural. Revista Estudios Agrarios, Mexico, no. 53-54. Retrieved from https://www.pa.gob.mx/publica/rev_53-54/analisis/emprendedurismo.pdf

Monsalve Basaúl, F. (2003). Los teletrabajadores. Revista de Derecho de la Universidad Católica de la Santísima Concepción, Santiago de Chile, no. 11.

Muñoz Gutiérrez, R. (2014). Innovación a la mexicana. Más allá de romper paradigmas (1st ed.) Mexico, Penguin Random House Grupo Editorial.

Olivares Alonso, E. (2014, December 23). Jóvenes mexicanos prefieren tener empresa propia o ser freelance. La Jornada en línea. México. Retrieved from http://www.jornada.unam.mx/2014/12/23/sociedad/035n1soc

PwC, the University of Southern California and the London Business School. (2013). Millennials value greater flexibility, appreciation, team collaboration and global opportunities. Retrieved from https://www.pwc.com/gx/en/hr-management-services/pdf/pwc-nextgen-study-2013.pdf

Reuters Staff. (2017, January 5). Uber driver is employee, not freelancer: Swiss agency. Reuters. Zurich. Retrieved from https://www.reuters.com/arti- cle/us-swiss-uber/uber-driver-is-employee-notfreelancer-swiss-agen- cy-idUSKBN14P0J9

Sociedad de la información incluyente: análisis sobre la región de América Latina y el Caribe. (n.d.). Retrieved from http://iibi.unam.mx/publicaciones/255/acceso_abierto_informacion $\% 20$ sociedad $\% 20 \mathrm{de} \% 201 \mathrm{a} \% 2$ 0informacion\%20incluyente $\% 20$ Egbert\%20Sanchez\%20Vanderkast.html

TagCDMX. (2017). Atipica, una startup mexicana contra la discriminación laboral. Televisa S.A. de C.V. Retrieved from http://tagfestival.com/2017/05/09/ atipica-startup-mexicana-contradiscrominacion-laboral/

Téllez Valdés, J. (2008). Derecho Informático (4th ed.). Mexico, McGraw-Hill

Téllez Valdez, J.A. (2007). Teletrabajo. Panorama Internacional de Derecho Social (1st ed.). Mexico, Instituto de Investigaciones Jurídicas de la UNAM. Retrieved from https://archivos.juridicas.unam.mx/www/ bjv/libros/5/2458/43.pdf

United Nations Children's Fund. (2016, January). Minimum Legal Ages and the Realization of the Rights of Adolescents. A review of the situation in Latin America and the Caribbean, UNICEF. Retrieved from https://www.unicef. org/lac/20160406_UNICEF_Edades_Minima_Esp(1).pdf Valles Santillán, G.G. (2017). In "Los millennials y la Constitución Política de los Estados Unidos Mexicanos de 1917: Perspectivas y retos a 100 años de su promulgación. La Constitución de 1917. Cien años después, Mexico, UJED and others. 